\title{
Postsecular democracy and the reign of God: Reading Habermas and Moltmann in South Africa
}

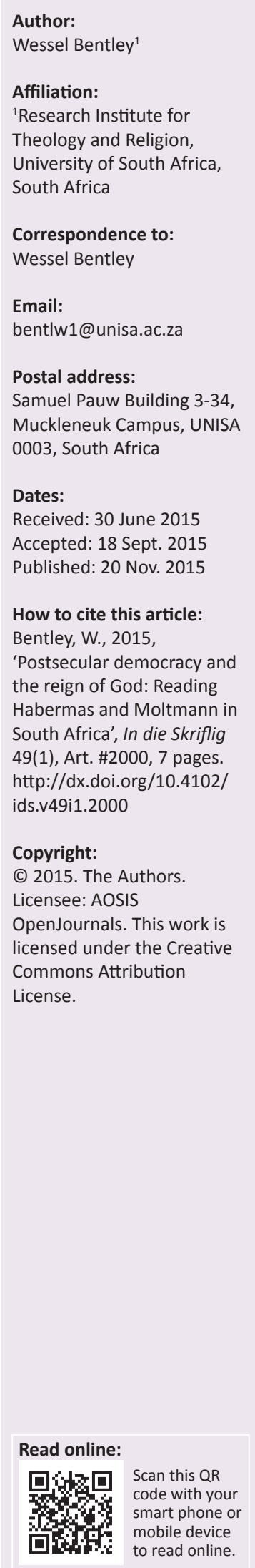

Governed by a liberal constitution, the South African democratic project is progressively finding its own identity. Being a democracy in Africa has unique challenges, as this system of governance needs to be contextualised by integrating African culture, history and memory into a political model which will promote sustainable participatory citizenship. This article engages, from a South African perspective, Habermas' model of a postsecular democracy and Moltmann's understanding of 'Reich Gottes' in Ethics of Hope. This article proposes an integrated relationship between responsible citizenship (Habermas' postsecular democracy) and a Christian social conscience (Moltmann's 'Reign of God' ${ }^{1}$ for the South African context.

Postsekulêre demokrasie en die koninkryk van God: in gesprek met Habermas en Moltmann vanuit 'n Suid-Afrikaanse perspektief. Die Suid-Afrikaanse demokrasie wat gegrond is op ' $n$ liberale grondwet, is geleidelik besig om 'n eie identiteit te vind. Demokrasie in Afrika ervaar unieke uitdagings en moet derhalwe gekontekstualiseer word deur die Afrikakultuur, geskiedenis en geheue in 'n politieke model te inkorporeer wat beoog om houdbare en deelnemende burgerskap te bevorder. Hierdie artikel tree vanuit 'n Suid Afrikaanse perspektief in gesprek met Habermas se model oor postsekulêre demokrasie sowel as met Moltmann se verstaan van 'Reich Gottes' in Ethics of Hope. 'n Geïntegreerde verhouding tussen verantwoordelike burgerskap (Habermas se postsekulêre demokrasie) en 'n Christelike sosiale gewete (Moltmann se 'Koninkryk van God') binne die Suid-Afrikaanse konteks word derhalwe deur hierdie artikel ondersteun.

\section{Introduction}

It seems counterintuitive to mention 'Postsecular democracy' and 'Reign of God' in the same sentence. After all, is the growing secularisation of the world not suggesting that there should be an almost complete separation of politics and religion? When speaking about democracy, secular democracy in particular, sharp distinctions are commonly drawn between the place of religion and the function of the state. This said, it is interesting to note on how many occasions South African leaders in politics and the judiciary have blurred the lines between religion and state. For instance, the media went into a frenzy when President Jacob Zuma suggested in 2008 that 'The ANC will rule until Jesus comes back home' (Hlatswayo 2008), and then in 2014: 'God must send Jesus again' (Mthethwa 2014). At the time, both these comments were downplayed as being uttered in a figurative. A more literal statement was nevertheless made in the same year (2014) by the Chief Justice of the Constitutional Court, Mogoeng Mogoeng, when he said: 'I believe that we can only become a better people if religion could be allowed to influence the laws that govern our daily lives, starting with the Constitution of any country' (Mogoeng 2014:4). This statement, in particular, implies that there are not only points of contact, but that there should be an inseparable integration between religion and politics, particularly in the South African constitutional democracy. The question this article seeks to address is whether there is in fact an overlap between the notions of 'postsecular democracy' and 'the Reign of God' and what this means for the South African context.

\section{Democracy in Africa}

From the outset, a well-known fact needs to be reiterated, namely that the term democracy cannot be used in a generic sense. As a form of government, which is theoretically constituted by the

1.Although the English translations of Moltmann's works refer to "Reich Gottes' as the "kingdom of God" i prefer to translate this to as 'the reign of God'. I believe this to be a more accurate translation of what Moltmann conveys as his image of the establishment of God's reign. It is not so much concerned with the establishment of a certain socio-political order or system, but the outworking of God's intention for life as summed up in the two-fold law of love. The reign of God is therefore not concerned with what would happen if God is King, but what life would look like when it subjects itself to the eschatological hope God presents. 
will of eligible citizens, democracy has historically morphed according to the context in which it is practised. It would be a travesty, for instance, to superimpose generalised Western understandings of democracy onto the African continent. Western democracy and African democracy are not synonymous terms. Furthermore, we cannot speak of Western democracy or African democracy, but rather of democracies, for there are varied expressions of democracy in both these geo-social regions, subscribing broadly to either Western or African ideological-political democratic frameworks. Seth Asumah (2014:418) correctly states that African democracies are fundamentally different from their Western counterparts, in so much as African democracies are exposed to unique challenges - often challenges which seemingly undermine fundamental and traditional assumptions pivotal to Western expressions of democracy.

One such challenge is African democracies' exposure to a wide range of diversity whilst Western democracies depend on the ideal of uniformity (to some degree) amongst its constituents. Democracy in the United States, for instance, has a strong religious flavour, where Christianity and belief are core issues in political discourse (Rieger 2012:21). African democracy has to contend with a greater measure of diversity, not only in population groups, but also religion, culture, language, et cetera (Asumah 2014:418-419). Asumah (2014) outlines the problem of African democracy in the following way:
... the democracy project in Africa is confronted with irrepressible challenges because Western procedural democracy, as a measure, is socioculturally different from African indigenous political cultures; unless the African people are willing to reframe new relational democratic models that will combine diversity and indigenous political cultures of Africa with the best democratic values and practices from the West to promote and sustain democracy, develop new economic measures in order to improve the human condition, and promote efficacy of their own polities, the democracy project in Africa will succumb to failure- prone policies and actions of predatory regimes to the detriment of democracy itself - which could be lethal for the continent in the twenty-first century. (p. 406)

African perceptions of Western democracy are further tainted by historical images of it being associated with '... slavery, racism, classism, elitism, sexism, homophobia, Afrophobia, Islamophobia, and androphobia' (Asumah 2014:409). Added to this is a fear that democracy is used by the West as an instrument through which it exercises a form of neo-patrimonial rule, manipulating African politics in order to gain for itself resources that would serve its own interest and not necessarily the interests of the communities or nations of the African continent (Cheeseman 2015:13-15). Africa has had to form its own democratic expressions. This was already evident in the work of Sklar (1983:11-17) in the 1980s, where a differentiation was made between five broad categories of African democracies:

1. Liberal democracies, where governments are limited by law and where citizens live in freedom of association, thriving on accommodating a diverse range of differences in its population. The Republic of South Africa serves as an example of this form of African democracy. ${ }^{2}$

2. Guided democracy, a form of developmental dictatorship, whereby those democratically elected to office rule beyond the reach of public accountability, for example Zimbabwe.

3. Social democracy, where the main focus of the democratic project is to minimise social inequality. Tanzania serves as example.

4. Participatory democracy, where the emphasis is on building a reciprocal relationship between democratic political institutions and participative private social institutions. Botswana is placed on the platform here.

5. Consociational democracy, which is a form of liberal democracy, but with the addition of specified arrangements to protect the vital rights of diverse cultural groups. Here, Nigeria is offered as an example.

These examples can obviously be contested on many levels, but I suggest that the broad categories are still valid descriptions of democratic expressions found at present. We cannot go into detail here regarding the different expressions of democracy in Africa, but need to focus specifically on the South African democratic project. ${ }^{3}$ Can the South African democracy be described as a Habermasean postsecular democracy and, secondly, how can the South African democratic project be described in light of Moltmann's 'Reign of God'? If it can be described as such, is there an overlap then between these concepts?

\section{Is the South African democracy a Habermasean postsecular democracy?}

Before we can address this question, another question first needs to be asked: What does Habermas mean by the term postsecular? Already in his monumental work, The structural transformation of the public sphere: an inquiry into a category of bourgeois society (Habermas 1989), he describes the formation of constitutional democracies in Europe, which led to his understanding of postsecularism as the result of certain social and economic advancements. Starting with the relationships between nobility and their subjects, Habermas (1989:14) explains that with the emergence of early finance and trade capitalism, those who were involved in trade as well landowners found a voice in the public sphere and could participate in the discourse of what they considered to be issues relating to the wellbeing of society as a whole. With the accelerated growth of household economies and the introduction of the printed press (Habermas 1989:21), Europe saw a broadening of the public sphere, where citizens became more independent from nobility, raising their own beliefs concerning what

2.This example as well as the example in the following point is my own. Examples in points 3-5 are given by Sklar (1983) and is based on the data at the point of his research.

3. Habermas employs the term project as he describes democracies as dynamic and unfolding socio-political states of governance. Democracy is subject to context, the composition of the electorate, economy as well as external influences such as international political trends, multinational corporate activities, the media and international public sentiment, which are some of the most prominent factors. international public sentiment, which are some of the most prominent factors. but is subject to change as history unfolds. 
they deemed to be good for society (p. 222). The outcome of this process was the formation of democratic systems, whereby those who participated in it had a voice in the formation of a state, which defined the local democratic project.

Of course the danger existed in each society, which had been historically structured and shaped by institutional religion (which had either overt or covert reciprocal ties with nobility) to oscillate to the other extreme, namely pure secularism - which limits or excludes the influence religion has on the formation and functioning of a democratic society. Nevertheless, Habermas warns against this danger and argues for a more moderate form of democratic society, emphasising the point that even religious communities form part of the broader community and hence have a role to play in it. Hereby a first definition: Postsecular democracy implies a form of democratic governance, which makes space for all eligible voices in society to contribute to the democratic project. This includes religion. ${ }^{4}$ Habermas and Ratzinger (2010) state that:

[T] he expression 'postsecular' does more than give public recognition to religious fellowships in view of the functional contribution they make to the reproduction of motivations and attitudes that are societally desirable. The public awareness of a postsecular society also reflects a normative insight that has consequences for the political dealings of unbelieving citizens with believing citizens. (p. 46)

More will be said at a later stage regarding Habermas' views on religions' contributions to democratic societies. According to this first definition, South Africa fits the mould. Not only does the South African Constitution (Republic of South Africa 1996) make space for freedom of religion, freedom of expression and freedom of association, but the nation's formal symbols include the notion of religious participation in the building of the South African democratic project. The national anthem, for instance, starts with an invocation: 'Nkosi sikelel' iAfrika', meaning 'God bless Africa'. In my view, the value of the South African Constitution is that it goes to great lengths to define and defend the rights of not only minority groups and individuals, but includes as far as possible a great array of communities who, at face value, may have differing perspectives when it comes to issues of beliefs or convictions. ${ }^{5}$ The South African democratic project recognises the unique contributions of all its citizens - even that of religion. Hence, neither falls within the category of a religious state, nor of a purely secular state. Habermas' postsecular democracy fits the South African context on this count. This, by default, raises the expectation that, whilst existing under the same socio-political construct, each person, group and religion has a responsibility to be

4. Habermas argues that as much as religion has a role to play in the democratic project, so the secular state should create space for religion to make project, so 'The secular state should create space for religion to make contribution. "Thus it [the state] may not demand anything of its religious citizens which cannot be recon
(Habermas 2010:21).

5.Religious communities, for instance (of which most have convictions that oppose same-sex relationships), enjoy equal protection under the Constitution to that of citizens who are both of same-sex orientation and/or are within same-sex relationships. actively involved in contributing towards the South African democratic project.

A second defining point is this: Postsecular states move the power of public policy from politics to society - the ideal being a self-legislative democratic community (Habermas 2006:9). The challenge in African democracies is that the Western notion of democracy and the notion of self-legislation by the public sphere (as an ideal), is often challenged by the level of diversity that exists within the African continent. Because the South African Constitution affords diverse groups equal weight in terms of their ability to contribute towards public policy and legislation (through representatives in public office), one finds in the Constitution a general 'spirit of inclusion'. Take for instance the matter of language diversity in South Africa. If policy was left to politics alone, then South Africa may have had one or two official languages. Instead, the South African democracy cannot do anything else but afford nine different languages the status of official languages in this region. The liberal nature of the South African Constitution, with a wide scope of protection for diverse groups, already testifies to the point that, according to this definition too, South Africa can be seen as a postsecular State.

A third definition is that postsecular democracies are dynamic. Habermas (2011:28) states that any democracy can at best be described as a project. To Habermas, the democratic project is always context and historically specific, a dynamic outworking of the participation of those who commit themselves to the democratic framework that defines a people and finds legislative self-expression in the constitution of such a democratic system. Governance is, for this reason, not only the responsibility of those who occupy public office, but rests in the hands of the electorate. Bohman, when speaking about the responsibility of civil participation in democracies, makes the following point: there is '... an equitable distribution of the burdens of citizenship' (2013:185). As citizens experience the outworking of public policy, they have within their reach the duty and responsibility to affect change where and when it is needed. Habermas (2006:9) points to a possible weakness in this arrangement, namely that public sentiment is often moulded by the power of the media, which then raises questions about the importance of media-freedom and State interest. With the three-tier structure of governance in South Africa, one can deduce the following: The intention of the democratic structure in South Africa is to give as much voice as possible to the electorate in terms of municipal, provincial and national governance. Whether this actually materialises in practice is a question for another article. Here too, South Africa complies with the notion of a postsecular democracy.

\section{Summary of Moltmann's understanding of the reign of God}

When Jürgen Moltmann uses the term 'Reich Gottes', one is immediately confronted with a complex concept, which 
involves both considerations in dogmatics and Christian ethics.

From a doctrinal point of view, Moltmann sees the reign of God as Trinitarian in nature, with Christ as the central figure, ushering in the reign of God into the domain of creation. In The Crucified God, Moltmann (1993) provides a doctrine of God, where God is not passively awaiting creation's recognition and intentional journey towards his reign. Instead, God manifests and participates in creation's realm of time and space, and primarily through the incarnation, life, death and resurrection of Christ makes the reign of God a reality in the world (Moltmann 1993:338). The Son reveals the 'Kingdom of the Father' (Moltmann 1990b:142-146) and the Spirit empowers those who respond to the Son's call of 'Follow me' to be participants in establishing the reign of God in the world (Moltmann 1981:212; 1992:289-299; 1997:229-247).

However, Moltmann (1981:192) warns against the appropriation of a 'divine monarchy's image to legitimise the use of religion for the domination of the world in all its different facets'. The kingdom of God is essentially a kingdom of freedom (Moltmann 1981:191-222), meaning that, although humanity has the power to exercise freedom (through self-determination, dominion over nature and belief), the kingdom of God invites humanity to exercise its freedom by choosing a form of life, which is beneficial for the building of community (Moltmann 1981:213-216). God therefore does not reign 'from the top-down', but the reign of God is manifest in and through the community, which participates in God's community-building project.

Thenotion of human participation in the Missio Dei is reiterated in Moltmann's recent work Ethics of Hope (2012): 'In Christian faith we see the world in the light of the resurrection and live in the certainty of Christ's victory' (p. 20). The reign of God is primarily eschatological in nature, where the consummated reign of God, as the 'eternal Sabbath' is set before creation ${ }^{6}$ as a reality from which God draws creation to himself. From this notion, 'we hope in so far as we can see into the sphere of future possibilities. We undertake what we think is possible' (Moltmann 2012:3). The world, seen 'sub specie aeternitatis' [from the perspective of eternity], is held accountable for the vision of God's reign and it is from this premise that Christians experience the existential outworking of the reign of God in their spheres of reality (Moltmann 2012:5). Before the impact this doctrine has on the South African context is addressed, the other side of the coin, namely Moltmann's understanding of God's reign in terms of Christian ethics, will be addressed first.

Moltmann does not separate dogmatics from ethics - they are two sides of the same coin: What we believe impacts on the way we live, and how we live speaks about our inner beliefs. This is a notion Moltmann shares with Karl Barth

6.In The Coming of God (Moltmann 1996), Moltmann does not limit the eschatological reign of God to humanity or humanity's salvation, but carefully plots how the reign of God is realised on different levels. He calls these levels 'Personal eschatology', 'Historical eschatology', 'Cosmic eschatology' and 'Divine eschatology'.
(1975:782-783, 788, 790). The notion of God's reign is not merely a speculative dogmatic formulation for Moltmann, but impacts on the expression of Christian life even in the domains of politics and society. Commenting on this aspect of Christian participation in society, Moltmann (2012) observes:

The state is the legally constituted community of citizens and their unified social community. It is not characterised as 'the powers that be' in the first place because of its monopoly of power. The foundation of the political community is law. The Christian community certainly sees the state order of the civil community as an order of divine grace but mainly as an exponent of the kingdom of God - outside the Christian community but not outside the lordship of Christ. (p. 22)

Further to this is Moltmann's understanding that theology itself is deeply political in its orientation and requires from religious traditions a recognition of their roles in civil society (Stanley 2008:478). As Christian communities pledge their loyalty to the Lordship of Christ, so they demonstrate the ethics, which is associated with the teaching of Christ, being an ethics of discipleship, which in turn is an ethics that anticipates the reign of God (Moltmann 2012:38). This does not, as one would suppose, imply that Christians, in their demonstration of Christian ethics, separate themselves from politics or society (Moltmann 2012:35-37). To Moltmann (2012), Christian ethics is primarily an exercised ethics, which requires context. There is no other context for the Christian to practice their faith (and ethics) than the existential realities in which they find themselves. Moltmann (2012) notes that:

Christian ethics should first and foremost put its stamp on a form of living which accords with Jesus' way of life and his teaching. That is where its identity lies. The question about general relevance then follows, but it cannot take first place. (p. 25)

Thus, to speak of Christian ethics is a question of identity and the authentic expression of this identity within a particular context.

Moltmann (2012:181) understands that Jesus '... pioneered a great "reevaluation of values"'. These were values, which pertained specifically to political, economic, social and religious questions in Jesus' context. It is my view that, for the Christian in 21st century South Africa, the values Jesus promoted are not statically fixed in Jesus' time and place, but can be studied, contextualised and applied to the present political, economic, social and religious questions facing us today. This 'eschatological', or, shall we say, 'unfolding' nature of God's reign as promoted in Jesus' teaching, debunks the notion that any talk of the reign of God is purely transcendental, but that, by its very nature, is existential and contextually grounded (Moltmann 1990a:40; 2012:184-186). To Moltmann (1992:246-251; 1997:38-42), the proclamation of God's reign is the responsibility of the church and is principally a message saturated with a promise of hope. Hope is the church's assurance of proclaiming God's great future for the world (Moltmann 2012:36). For me, this 'hope' is the pivotal place of assessing the intersection for the South African question of public participation in terms 
of Habermas' postsecular democracy and Moltmann's responsible citizenship with reference to the reign of God.

\section{Points of intersection}

Moltmann (2012:3) starts his ethics of hope with the Kantian question: 'What can I hope for?' In Habermasean theory, it is precisely this question which political theology brings to the table in the context of an inclusive postsecular democracy. After more than two decades since the transformational elections in South Africa, it is a question that stands at the forefront of public discourse. Will South Africa succeed? Is there hope? From a particularly Christian perspective, is the establishment of a Christian state the key to the South African hope? These are rhetorical questions, but questions which will, nevertheless, seek to be addressed in the following section. For this part of the discussion, I would like to draw on Moltmann's principles of his ethics of hope. These principles form a framework that Moltmann extracts from Isaiah 2:4. The principles read as follows: 'Not to turn swords into Christian swords, not to retreat from turning swords into ploughshares, but to make ploughshares out of swords' (Moltmann 2012:xiii). By 'swords' I would like to argue that we can interpret Moltmann's use of the word in this discussion as referring to both the roles of responsible citizenship and, for Christians, the responsibility of offering a Christian social conscience.

\section{Not to turn swords into Christian swords}

Firstly, when it comes to the discussion of responsible citizenship, Moltmann argues that responsible citizenship does not mean that this term should be generalised to mean 'Christian citizenship' for the entire population.? When Christians speak about responsible citizenship, a common discourse, which comes to light, is the suggestion that the only answer is to be found in the formation of a 'Christian State'. ${ }^{8}$ This suggestion is fundamentally not about Christian norms or responsible citizenship, but is, in effect, a discussion about power. Moltmann (2012:24) argues that where swords are turned into Christian swords, the concept of God's reign is taken too literally and is hence misunderstood, especially when appropriated into the sphere of politics. History tells us that where societies forced the idea of responsible citizenship to mean Christian citizenship, there has been a harsh backlash against Christianity, including both a public and political resistance to the notion of an absolutist religious understanding of citizenship (Moltmann 2012:24).

This, however, does not mean that one should surrender religion completely for the sake of secularism. For Christians to be responsible citizens means to Moltmann (2012:xiii) 7.Moltmann (2012:23-25) is quite vocal against what he terms 'Theocratic
democracy'. The general imposition of Christianity on society leads to a social
resistance to religion and does not promote religion's standing in socio-political discourse.

8.See Forster's argument (2012) against the formation of religious states. 'Religion is continually being "made" using politics, and that leads souls astray. Politics are continually being "made" using religion, and that is the ruin of the worldly order' (Moltmann 2012:10). that they have to contribute to society by adhering to their understanding and practice of Christian ethics. ${ }^{9}$ They do so within the context of knowing that their contribution is received in the environment where there is an understanding of the equality of all citizens (Moltmann 2012:166). Even when Christians have strong opinions on social questions, they need to admit that they '... have no better ideas about the solution of ethical problems in today's society than other people' (Moltmann 2012:25). Their healthy participation in society removes the temptation to deify the state (Moltmann 2012:23) or to appropriate the state for its own purposes. At the same time, the state should recognise the value of a Christian social contribution and not trivialise this voice in light of the diversity, which exists in society (Moltmann 2012:31).

This is where we find an overlap between Moltmann and Habermas: 'Habermas goes well beyond entertaining the thought that religion could also serve as one among many voices of moral insight in the public sphere' (Gordon 2013:196). This is not to say that religion should refrain from offering a moral perspective. On the contrary, it is precisely the religious contribution to moral frameworks and social cohesion, which assists postsecular democracies to frame its moral and societal boundaries (Habermas 2010:16; Bentley 2014:6). With particular reference to the role of religion in society, Jansen (2011:991) comments that there is an inseparable link between the expression of faith and socio-political justice. It is interesting to note in this instance how postsecularists afford religion the role of being somewhat a voice of norms and values in society, especially in light of secularism's insistence that religion does not have a monopoly on morality. ${ }^{10}$ Although religion may offer a voice, it is never the voice, and should not be. Habermas and Moltmann agree on this point. Habermas (2011:25) advocates for the translation of religious language into secular language for the sake of avoiding the marginalisation of its contribution by virtue of the message coming across as patronising, whilst Moltmann (2012:31) appropriates Lindbeck's view, that '... religion ... can only be understood in light of its own presuppositions'. Habermas (2010) frames his understanding as follows:

Instead of grudging accommodation to externally imposed constraints, the content of religion must open itself up to the normatively grounded expectation that it should recognize for reasons of its own the neutrality of the state towards worldviews, the equal freedom of all religious communities, and the independence of the institutionalized sciences. (p. 21)

This means that religion should, first of all, know its frame of reference as well as its methodological limitations. From here it needs to contextualise its message into a language, which is both relevant and understandable in general social

\footnotetext{
9.The South African theologian, Dirkie Smit, concurs with this view. He (Smit 2007:439) states: 'The church exists always in the world and as part of the world, whether or not it wants to, and thereby impacts public life in varied and complex ways, regardless of whether it is aware of this.'

10.De Gruchy (2007:30) concurs with this view: 'Secular democratic society is not by definition anti-religious or unconcerned about moral values, but dependent on them.'
} 
discourse. In the South African context, religions need to take their role as participants in the democratic project seriously. This participatory citizenship, which includes religion, is for Habermas the hopeful point towards which postsecular democracies should move.

At the same time, the reign of God is, from a Moltmannian perspective, the call to Christians to make a Christian contribution to society. There is value in a Christian contribution. Sometimes the ethics of God's reign (it could, however, be subjectively interpreted) may be at conflict with the interests of the state. Then again, even a critical voice is one worth listening to, for when taken seriously and when engaged with in a respectful manner, it endorses the idea that there is space for even religion in the South African democracy, but more so, that society, as a whole, may benefit from its offering. To become an exclusively 'Christian State' would put South Africa back in the same mould as under the apartheid regime.

\section{Not to retreat from turning swords into ploughshares}

What does this mean? I propose that it refers to the retreating by religion or citizens in general from contributing towards either the reign of God and/or the democratic project as a whole. Perhaps this is done when hope is lost? Moltmann draws religion's attention to two ways in which religion (Christianity in particular) withdraws from the process of working towards the reign of God. The first is by becoming conformist (Moltmann 2012:40), and the second is by becoming separatist (cf. pp. 25-34). If Christians are merely conformist, then they fail in their responsibility to offer a Christian voice in society. Moltmann (2012) offers this challenge to conformists:

Christian responsibility for the world requires an ethics for changing the world, based on the righteousness and peace which we believe in and try to live, in the discipleship of Christ. (p. 206)

The opposite of being conformist, is becoming separatist, which is equally dangerous. Yes, the reign of God by nature offers an alternative in society (Moltmann 2012:xiii), but this does not mean that Christianity should apply itself in a passive-aggressive manner, viewing itself as a pietistic model of what society should look like. On this count Moltmann (2012) engages Hauerwas, challenging his stance as being subtly separatist:

We are not told: 'Blessed are the peaceful' but 'blessed are the peacemakers'... so the church of Christ is not a 'peaceable kingdom', as Hauerwas calls it; it is the peacemaking kingdom. (p. 33)

Habermas (2008:128) argues that, where citizens find themselves in the context of a purely secular state, the separation of faith from social responsibility would be insisted upon (cf. Jansen 2011:978), but the opposite is true for postsecular democracy. Withdrawal, in whatever form, would see the collapse of postsecular democracy as it is in the diversity of personal, public and even religious voices that the mosaic is shaped of a reality bigger than merely the sum total of the individual contributing agencies. Diversity and diverse voices giving true and authentic expression to their convictions in society underpins Habermas' postsecular democracy.

In the South African context, withdrawal by Christians and/or the withdrawal of different social groupings will prove detrimental to the realising of a South African hope. Conformism, whether religious or secular, simply sweeps the ongoing scourge of nepotism, corruption, marginalisation and the exploitation of the working class and poor under the carpet. Separatism, like that of racial groupings calling for their own independent 'homelands', or the untouchability of the politically connected, or the growing disillusionment in society thinking that 'my vote will not matter', does not add one single bit of value to nation-building, job creation or the practice of political and economic accountability. If this is the case, then hope is dying a slow death. What is then the alternative?

\section{To make ploughshares out of swords}

Speaking about the Christian role in contributing towards the reign of God, Moltmann (2012:35-44, 60, 231-234) suggests a third alternative (as opposed to a conformist or a separatist church), namely an engaging church. The church in a democracy needs to be an active and trusted entity, which contributes positively to society as a whole. Democracy depends on trust; without trust, everything falls apart. 'Trust is won through truthfulness and strengthened by honesty' (Moltmann 2012:167). Adversely, dishonesty sows fear and leads to struggles between groups instead of moving together towards a common goal. An engaging church, in accordance with its Christian ethics of hope, offers a message that is transformative and advancing in nature. Using Christian language, transformation is termed 'salvation'. An honest, engaging church, according to Moltmann (2012:37), offers the following four messages of salvation, whilst holding itself accountable to the same:

1. Salvation takes effect in the struggle for economic justice and against the exploitation of human beings by human beings;

2. Salvation takes effect in the struggle for human dignity against political oppression by other human beings;

3. Salvation takes effect in the struggle for solidarity against the alienation of human beings;

4. Salvation takes effect in the struggle for hope against despair in individual life. Without social justice there is no political liberty; without political liberty cultural alienations cannot be overcome; without cultural identity there is no personal hope and vice versa.

These four dimensions are interconnected, but different situations call for different priorities. There are varying gifts and tasks, but there is one Spirit and one salvation. 'Salvation is all-embracing, if we embrace the world with the heart of Christ'. 
In this way, by providing a Christian social conscience that contributes positively towards the building of communities, the swords are turned into ploughshares.

Habermasean postsecular societies, on the other hand, create space where the public sphere engages with matters of policy, social problems and possible solutions (Graham 2013:xvi). This is only possible by taking seriously the contribution that each perspective makes in forming healthy communities (Habermas 2011:25). This includes the voice of religion. Postsecularism moves away from the idea that religion is an obstacle to democracy, or even that it should be merely tolerated (Bohman 2013:179). The internalisation of diversity and plurality becomes the transforming factor of democracy itself, whereby the locus of democracy is not found in a specific body, for instance the state, but is the participation of all its constituents. This form of citizenship has, as eventual outcome for society, a self-arrangement or alignment, which ideally is not patronising, but is the expression of unity amongst its peoples (Bohman 2013:185).

In South Africa, it is the function of the church, not only to proclaim the gospel, but to raise its voice for the sake and benefit of society as a whole. Similarly, active participatory citizenship, as defined by Habermas, turns the swords of diverse identities into the ploughshares of healthy and accountable communities (Habermas \& Ratzinger 2010:55).

\section{Conclusion}

To Moltmann (2012:151), the telos of creation is the reality of God' reign. This means God's indwelling in creation and what that means for all who form part of it. The goal of a Christian social conscience is not democracy. At the same time, it cannot divorce itself from its context. Habermas advocates for a participatory community made up of different voices, which together contribute towards a unified whole (Habermas \& Ratzinger 2010:32). Moltmann's framework (2012:xiii) here, in conversation with Habermas' socio-political theory, warns against superiority (turning swords into Christian or any other swords). It warns against withdrawal (retreating from turning swords into ploughshares), but celebrates the life and dynamism, which is brought about when individual swords are turned into ploughshares.

This article argues that there are common threads in both Habermas' understanding of postsecular democracy and Moltmann's 'Reign of God'. As a South African, I argue that the principles underlying both are founded on a positive hope; a hope which can move the South African democracy to realising the dream of being one in diversity.

\section{Acknowledgements Competing interests}

The author declares that he has no financial or personal relationships which may have inappropriately influenced him in writing this article.

\section{References}

Asumah, S.N., 2014, 'African relational democracy: Reframing diversity, economic development, and society-centred governance for the twenty-first century', in S.N. Asumah \& M. Nagel (eds.), Diversity, social justice, and inclusive excellence: Transdisciplinary and global perspectives, pp. 405-428, State University of New York Press, New York.

Barth, K., 1975, Church dogmatics: The doctrine of the Word of God, vol. 1, T\&T Clark Ltd., London.

Bentley, W., 2014, 'Structural transformation and democratic public spaces: Reflections on Habermas and the 2014 Tshwane State of the Capital City Address', HTS Teologiese Studies/Theological Studies 70(3), Art. \#2755, 8 pages. http:// HTS Teologiese Studies/Theological
dx.doi.org/10.4102/hts.v70i3.2755

Bohman, J., 2013, 'A postsecular global order? The pluralism of forms of life and communicative freedom', in C. Calhoun, E. Mendieta \& J. van Antwerpen (eds.), Habermas and religion, pp. 179-202, Polity Press, Cambridge.

Cheeseman, N., 2015, Democracy in Africa, Cambridge University Press, Cambridge.

De Gruchy, J.W., 2007, 'Public theology as Christian witness: Exploring the genre', International Journal of Public Theology 1(1), 26-41. http://dx.doi. org/10.1163/156973207X194466

Forster, D.A., 2012, 'God's Kingdom and the transformation of society', in W. Bentley \& D.A. Forster (eds.), Between capital and cathedral: Essays on church-state relationships, pp. 73-88, Research Institute for Theology and Religion, Pretoria.

Gordon, P.E., 2013, 'Between Christian democracy and critical theory: Habermas, B öckenf örde, and the dialectics of secularization in postwar Germany', Social Research: An International Quarterly 80(1), 173-202.

Graham, E., 2013, Between a rock and a hard place: Public theology in a post-secular age, SCM Press, London.

Habermas, J., 1989, The structural transformation of the public sphere: An inquiry into a category of Bourgeois society, Polity Press, London.

Habermas, J., 2006, Times of transition, Polity Press, Cambridge.

Habermas, J., 2008, Between naturalism and religion: Philosophical essays, Polity Press, Cambridge.

Habermas, J., 2010, 'An awareness of what is missing', in J. Habermas, M. Reder, J. Schmidt, N. Briekskorn \& F. Ricken (eds.), An awareness of what is missing, pp. 15-24, Polity Press, Cambridge.

Habermas, J., 2011, “'The political”: The rational meaning of a questionable inheritance of political theology', in E. Mendieta \& J. van Antwerpen (eds.), The power of religion in the public sphere, pp. 15-33, Columbia University Press, New York.

Habermas, J. \& Ratzinger, J., 2010, The dialectics of secularization: On reason and religion, Kindle edn., Ignatius Press, San Francisco.

Hlatswayo, R., 2008, 'ANC will rule until Jesus comes back', Sowetan LIVE, viewed 10 April 2015, from http://www.sowetanlive.co.za/sowetan/archive/2008/09/09/ anc-will-rule-until-jesus-comes-back

Jansen, Y., 2011, 'Postsecularism, piety and fanaticism: Reflections on Jürgen Habermas' and Saba Mahmood's critiques of secularism', Philosophy \& Socia Criticism 37(9), 977-998. http://dx.doi.org/10.1177/0191453711416083

Mogoeng, M., 2014, Law and religion in Africa: The quest for the common good in pluralistic societies, viewed 12 June 2014, from http://tinyurl.com/k7s9yrm

Moltmann, J., 1981, The trinity and the kingdom of God: The doctrine of God, SCM Press, London.

Moltmann, J., 1990a, Theology of hope: On the ground and the implications of a Christian eschatology, SCM Press, London.

Moltmann, J., 1990b, The way of Jesus Christ: Christology in messianic dimensions, SCM Press, London.

Moltmann, J., 1992, The church in the power of the Spirit: A contribution to messianic ecclesiology, SCM Press, London.

Moltmann, J., 1993, The crucified God: The cross of Christ as the foundation and criticism of Christian theology, Fortress Press, Minneapolis.

Moltmann, J., 1996, The coming of God: Christian eschatology, SCM Press, London.

Moltmann, J., 1997, The source of life: The Holy Spirit and the theology of life, Fortress Press, Minneapolis.

Moltmann, J., 2012, Ethics of hope, Fortress Press, Minneapolis.

Mthethwa, B., 2014, '2008 "ANC will rule until Jesus comes" 2014 "God must send Jesus again": Zuma', Times LIVE, viewed 10 April 2015, from http://www.timeslive. co.za/politics/2014/12/31/2008-anc-will-rule-until-jesus-comes-2014-god-mustsend-jesus-again-zuma

Republic of South Africa, 1996, The constitution of the Republic of South Africa, Act 108, Government Printer, Cape Town.

Rieger, J., 2012, 'Being a Christian in a "Christian country": Theological reflection', in W. Bentley \& D.A. Forster (eds.), Between capital and cathedral: Essays on churchstate relationships, pp. 21-39, Research Institute for Theology and Religion, Pretoria.

Sklar, R.L., 1983, 'Democracy in Africa', African Studies Review 26(3\&4), 11-24.

Smit, D., 2007, 'Notions of the public and doing theology', International Journal of Public Theology 1(3), 431-454. http://dx.doi.org/10.1163/156973207X231716

Stanley, T., 2008, 'Karl Barth and Jürgen Habermas: Transcendental aporias of global civil society', Political Theology 9(4), 477-502. http://dx.doi.org/10.1558/poth. v9i4.477 